\title{
The planner's subjective destitution: towards a hysterical-analytical triad of planning theory- research-practice
}

\author{
Die subjektive Destitution des Planers: zu \\ einer hysterisch-analytischen Triade von \\ Planungstheorie, Forschung und Praxis
}

https://doi.org/10.2478/rara-2019-0009

Eingegangen: 13. April 2018; Angenommen: 29. Januar 2019

\begin{abstract}
In this article, I set out different relationships between planning theory, research and practice, drawing on Lacan's "production of four discourses". I argue that each element of the planning theory-research-practice 'triad' acts as the discursive 'agent' and gives rise to particular kinds of 'subject-planner' (the 'master', the 'expert', the 'idealistic' and the 'pragmatic') with specific ideological upshots ('hidden' big other, 'feigned' big other, hysteria and subjective destitution). Primarily a theoretical discussion, the article is also partially underpinned by my own practical experience in planning. While Lacanian psychoanalytical theory has already entered the planning field, its deployment has been mostly centred on deconstructing both planning decision-making processes and the mediation of planners in creating and implementing plans. Hence, the attempt here is to look in more depth at the 'ambivalent' role of the planner as well as to bring in 'planning research', as a key, somewhat occluded, element within the discussion on bridging planning theory and practice. Further, in the literature there seems to be a sort of omnipresent assumption that 'valid' reflection on planning can only come from the 'outside', which in turn perpetuates the role of the academic researcher simply trying to decode and analyse what the practitioner does (or tries to do). Critical impressions from those 'out there', 'on the job', are still missing. They, far from mere anecdotic accounts, ought to comprise selfinflicted criticism triggered by a sense of discomfort with what's being done - by the hysterical question of "why am I a planner?" and "why I am doing this or that?"
\end{abstract}

Keywords: Planning theory, psychoanalytical theory, Lacan, discourse, uncertainty

Zusammenfassung: Ausgehend von Lacans „Produktion von vier Diskursen“, arbeitet der Beitrag verschiedene Beziehungen zwischen Planungstheorie, Forschung und Praxis heraus. Das Hauptargument des Artikels ist, dass jedes Element der ,Planungstriade' aus Theorie-Forschung-Praxis als diskursiver ,Agent' wirkt und somit bestimmte Arten von ,Subjekt-Planer' (der ,Meister', der ,Experte', der ,Idealist' und der ,Pragmatiker') mit spezifischen ideologischen Ergebnissen (der versteckte große Andere, der vorgetäuschte große Andere, Hysterie und subjektive Destitution) hervorbringt. Die theoretischen Diskussionen des Beitrags wurden durch meine eigenen praktischen Erfahrungen in der Planung inspiriert. Obwohl die psychoanalytische Theorie von Lacan bereits in das Feld der Planung eingeführt wurde, konzentrierte sich ihre Anwendung hauptsächlich auf die Dekonstruktion von sowohl Planungsentscheidungsprozessen wie auch der Vermittlung von Planern bei der Erstellung und Umsetzung von Plänen. Daher unternimmt der Beitrag

*Corresponding author: Ignacio Castillo Ulloa, Ph.D., Technische Universität Berlin, Institut für Stadt- und Regionalplanung, Fachgebiet Städtebau und Siedlungswesen, Ernst-Reuter-Platz 1 | BH 5-1, 10587 Berlin, Deutschland, E-mail: i.castillo-ulloa@isr.tu-berlin.de 
den Versuch sich tiefer mit der ,ambivalenten' Rolle des Planers auseinanderzusetzen und, ,Planungsforschung' als Schlüsselelement in die Diskussion um die Überbrückung von Planungstheorie und -praxis einzubringen. Weiter scheint es so, dass es in der Literatur eine Art omnipräsenter Annahme gibt, dass ,valide' Reflexion über Planung nur ,von außen' kommen kann. Dies führt zur Aufrechterhaltung der Rolle des akademischen Forschers als jenem Akteur, welcher analysiert und entschlüsselt, was der Praktiker tut (oder versucht zu tun). Kritische Eindrücke von jenen, die ,da draußen', ,im Job', sind, fehlen weitgehend. Sie sollten jedoch nicht nur Anekdoten sein, sondern selbstformulierte Kritik, ausgelöst durch ein Gefühl des Unbehagens mit dem, was getan wird - durch die hysterische Frage „Warum bin ich ein Planer?" und „Warum mache ich dies oder das"?

Schlüsselwörter: Planungstheorie, psychoanalytische Theorie, Lacan, Diskurs, Unsicherheit

\section{Introduction: Getting, hysterically, off the ox-cart}

At one time, practice was considered an application of theory, a consequence; at other times, it had an opposite sense and it was thought to inspire theory, to be indispensable for the creation of future theoretical forms. In any event, their relationship was understood in terms of a process of totalization [...] however [...] The relationships between theory and practice are far more partial and fragmentary. On one side, a theory is always local and related to a limited field, and it is applied in another sphere, more or less distant from it. The relationship which holds in the application of a theory is never one of resemblance. Moreover, from the moment a theory moves into its proper domain, it begins to encounter obstacles, walls, and blockages which require its relay by another type of discourse (it is through this other discourse that it eventually passes to a different domain). Practice is a set of relays from one theoretical point to another, and theory is a relay from one practice to another. No theory can develop without eventually encountering a wall, and practice is necessary for piercing this wall (Deleuze 1977: 205 f.).

Theory and practice are relational, depending for their continued viability on mutual referral. Theory, then, does not flow above everyday life in a detached way: It comes from some place, and it is the responsibility of analysis to return it there (Liggett/Perry 1995: 2).

In an editorial, Forester (2015) sparks debate around the question of the kind of research that might help planners become better. There is, according to the author, no definitive answer to that - something I personally cannot help but endorse. Yet, rather than understanding Forester's provoking question as a mere aporia, in this article I take on his call by stressing the role of research and its function as a mediacy within the never-ending theory-practice interaction. However, my aim is not necessarily to state the type of research that would ultimately enable planners to be(come) better (the assessment of 'better' is, in my view, far too problematic and requires a discussion of its $\left.o w n^{1}\right)$. Hence, the core question that I deal with in this article is how planning research ought to be (re)assessed to enable planning theory and practice to find a synergic balance. Incipient claims are: (i) that such equilibrium, given the innate tension between theory and practice, might as well be imperfect; and, more specifically, (ii) that a 'hysterical', as understood in Lacanian theory, change in the way planning research is carried out is necessary, in order to allow planning practice to be (more) 'pragmatic' while 'moving among theoretical points'. The attempt to tackle these two theses is, too, partly encouraged by my personal practical experience in planning, which was largely empirical and fuelled by what I came to determine as a universal(ising)/technocratic(ised) planning theory. Practice, in this sense, was deemed, as Gilles Deleuze observes in the quotation above, as a natural 'offspring' of theory, though there was an increasing divergence between what was theoretically supposed to happen

1 Affirming 'better', for starters, implies that planners are already 'good' at what they do; and that's when things get tricky. For instance, if a planner fulfils their 'official' tasks, it is very likely that, in the view of their superiors, a 'good' job is being done. This, of course, does not de facto make a planner indisputably 'good'. On the other hand, say a planner decides to bend the rules of formal planning to make it more enthralling and enhance citizen participation. People getting involved in the planning process will likely regard the planner as 'good' (as long as they're not paying lip service), whereas other stakeholders may not be as content. For either case, moreover, there would arguably be a particular type of research (let alone of practice and of theory) that could make planners 'better' - though, again, that's something inevitably permeated with subjectivity. And to make the issue even more convoluted, let's consider that a planner may "wish to be perceived as a good planner or academic" and to be "perceived as 'good' means doing the correct thing, having the correct values, and acting accordingly" (Gunder 2011: 205; see also Gunder 2004). And this line of reasoning can go on and on. 
and what actually occurred - i.e. practical relays did not gravitate towards theoretical points.

In spite of such inconsistency, practicing planning 'under the spell' of a totalising theory - that allegedly prevents the encounter of walls or obstacles and the irruption of 'other' discourses that may displace it - continues to be pursued. Making sense of such conundrums is indeed a bit of a hassle, though very pertinent if alternative paths, redefining the interconnection between planning theory, research and practice, are to be explored. This, moreover, must be a relentless task, even a sort of indulgence, which resembles the defiance of disentangling a Gordian knot to fathom out, a second later, that it is made out of an infinite number of other knots. Furthermore, such an undertaking is anything but simplistic: it must be prompted, as I mentioned above, by hysteria; that is, by confronting the inner discomfort with what we are (doing or being a part of). Eventually, it is possible to realise that we were riding the ox-cart all along and that we need to get off, as it were, to theorise, research and practice planning 'outside the box'.

Anti-essentialist Lacanian theory, in such an account, represents an 'untying path' as well as a means to take a 'hysterical jump'. Now, turning to psychoanalysis apparently not akin to planning - to shed light on the interrelationship(s) between planning theory, research and practice may well be regarded as adventurous and gratuitous. There is, notwithstanding, prolific literature that makes use of Lacan's 'redefinition of psychoanalysis' (see, inter alia, Gunder 2003a; Gunder 2003b; Hillier 2003; Gunder 2004; Gunder/Hillier 2004; Gunder 2005a; Gunder 2005b; Hillier/Gunder 2005) to further develop planning theory by insightfully reviewing - the still pervasive - modernist planning praxis in its diverse contemporary disguises. In addition, the key to fruitful argumentation resides on finding middle ground somewhere between an austere (dodging contact with other modes of thinking) and an overambitious (bringing in an unmanageable amount of perspectives) theoreticanalytical standpoint. As Friedmann (1998: 249), in regard to planning theorising, sustains: "theoretical austerity is [...] not the way to go. But writing in the plenitude of passion, across the entire gamut of modes of theory, runs the danger of saying too much too soon". To sum up, if the task of analysis, as Helen Liggett and David Perry affirm in their abovementioned quote, is to trace practical ways back to the 'theoretical springs' embedded in real life situations, psychoanalytic inquiry is arguably a useful drill to perforate the walls keeping planning theory and practice apart and to "reach far beyond the familiar scope of 'explanatory social science"' (Forester 2015: 148).

The article begins with an overview of Lacan's (2007 [1991]: $11 \mathrm{ff}$.) "Production of Four Discourses" to then set out different linkages between the realms of planning theory, research and practice. The premise is that, within the structure of each of the Lacanian discourses (the master's, the university's, the hysteric's and the analyst's), theory, research or practice operates as the 'agent' exerting one, or various, discourses, which, in turn, makes it the driving force establishing the nexuses. Every discourse produced is also affected by the splitting between the "subject of enunciation" and the "subject of enunciated" infusing inconsistency-inauthenticity (into the master), consistency-inauthenticity (into the academic), inconsistency-authenticity (into the hysteric) and consistency-authenticity (into the analyst) (Žižek 1993). Correspondingly, each discourse gives rise to a particular 'subject-planner' (the 'master', the 'expert', the 'idealistic' and the 'pragmatic') with a specific ideological upshot ('hidden' big Other, 'feigned' big Other, hysteria and subjective destitution).

That being so, within the planning theory-researchpractice triad, the 'master' and the 'expert' subjectplanner constitute two sides of the same coin to either bypass or subjugate research and thereby determine practice. Furthermore, a structural 'concealed'/'contrived' ideological order (i.e. a big Other) is created, via a universal(ising)/technocractic(ised) planning theory and articulated by the master's and university's discourse, to craft a "pseudo-Hegelian immediate coincidence of the opposites: action and reaction should coincide, the very thing that causes damage should already be the medicine" (Žižek 2003) - that is to say, sustaining the impression that the same (kind of) planning that fails is the only one that can correct it. Nonetheless, the 'idealistic' and the 'pragmatic' subject-planner, building on the discourse of the hysteric (critical researcher) and analyst (micro-practitioner), are thought to compose two sides of a 'counteractive' coin that triggers the hysteria and the subjective destitution of the universal(ising)/ technocratic(ised) theorist (i.e. both the 'master' and the 'expert' subject-planner). As a result, action and reaction are, first, separated and, then, kept apart, through the synergic differential-symbolic conjunction of planning critical-hysterical research and analytical (micro-) practice.

The article's 'not-a-conclusion' (I believe that there should not be an end of the line for this discussion) is an open invitation to reconsider, in its utmost manner, planning research to, then, call into question how 
planning theory, all too often, subdues research and practice as well as how fruitful critical theoretical debates sometimes cannot found practical relays either because they end up being a duel between fierce theorists attempting to impose their (new) paradigms, or due to their incapability of properly grasping unnameable (i.e. beyond what-is-yet-theoretically-known) practical instances. $^{2}$ As aforementioned, critical-hysterical planning research is pivotal to co-constitute planning theory, research and practice, in such a way that universal(ising)/technocratic(ised) theories be consigned to oblivion and critical-hysterical research together with analytical (micro-)practice aid planners to envisage the future and remember the past more pragmatically and dynamically. In other words, cutting off the attempt to force reality to adapt to megalomaniac visions of the future and, in so doing, reduce the use of 'catchy' labels to render meaningful practical situations that supersede theoretical discourse.

\section{Socially bonding through language: Lacan's Production of Four Discourses}

There's no such thing as a metalanguage (Lacan 1999 [1975]: 118).

While Lacanian psychoanalysis is not a totalised or totalising view of the world, it embodies, as Fink (1997: 129) notes, "a very powerful theory and socially significant practice". In addition, continues Fink (1997: 129), Lacanian theory is a discourse, not the ultimate one, nor "in and of itself, a discourse of power" though it "deploys a certain kind of power in the analytic situation". Lacan purposely uses the term 'discourse', rather than 'speech', to denote the "transindividual nature of language, the fact that speech always implies another subject, an interlocutor" (Evans 2006: 45). Discourse, therefore, "as a necessary structure that goes well beyond speech", "can clearly subsist without words. It

2 Gunder and Hillier (2007), building on Derrida's "aporia of undecidability", offer an alternative take on how to grasp such 'unnameable' planning practices. The authors sustain, by and large, that knowledge production, action and responsibility, amid other dimensions of the world (including, of course, planning practice) must be dealt with while taking into account an inherent lack of certainty. Gunder (2008: 196), furthermore, sees undecidability as a dimension of the Lacanian Real (see note 5), for "there is never complete or perfect knowledge; something is always lacking". subsists in certain fundamental relations which would literally not be able to be maintained without language" (Lacan 2007 [1991]: 12 f.). ${ }^{3}$ Given that Lacan surpasses the content of a discourse and focuses, instead, on "the formal relationships that each discourse draws through the act of speaking", his discourse theory "is to be understood primarily as a formal system, i.e., independent of any spoken word as such" (Verhaeghe 2001: 21; italics in the original). Discourses, hence, can be seen as a sort of encasement that determines the limits of thought, communication, and action.

Lacan, in time, revisited his definition of discourse (as he did with other of his key formulations like "the Real", "the Other", "object petit a"). Still emphasising intersubjectivity, he came to designate discourse as "a social link, founded in language" (Lacan 1999 [1975]: 17), which not only precedes the concrete enunciated word, but also establishes the framework of the communication act. "This effect of determination", what is more, underscores "the Lacanian basic assumption, namely that each discourse delineates fundamental relationships, resulting in a particular social bond" (Verhaeghe 2001: 21; italics in the original). That being so, there are four possibilities to 'socially bond'; to provide the symbolic network that controls intersubjective interactions with an enunciation: the discourse of the master, the discourse of the university, the discourse of the hysteric and the discourse of the analyst (Lacan 2007 [1991]: 11 ff.). ${ }^{4}$ Moreover, "Lacan's account of four fundamental

3 By way of clarification, it is noteworthy that the term 'language' in English corresponds to two different terms in French: langue und langage. For Lacan the former designates specific languages (e.g., French, English), whereas the latter refers to the system of language in general irrespective of any particular language. Since what interests Lacan is the general structure of language (langage), and not the differences between specific languages (langues), it is langage what is almost all of the time meant by language when consulting an English translation (Evans 2006: 99).

4 Lacan, as was usually the case, continuously developed his theory of four discourses from Seminar XVII, where they were introduced, all the way to Seminar XX and beyond (a period during which he revised them to a certain extent). While the theory's inception is often associated with the Paris revolts that unfolded in May of 1968, it is Lacan's critical assessment of what he believed were extreme orthodox - and thus deficient - readings of the Oedipus complex that can be assessed as the outset of the production of the four discourses. For more in-depth discussions, see Evans (2006: 45 ff.), Verhaeghe (2001: 25 ff.), Fink (1997: 129 ff.), Žižek (2006b) and, particularly, Bracher (1993: 53 ff.) and Bracher (1994). The authors cited here engage in their own particular way when describing the four discourses; due to space limitations, I provide a succinct description of each discourse building, somewhat tangentially, upon them. 


\begin{tabular}{c|cc} 
Speaker & Receiver \\
Agent & Other & Domain of the "subject of enunciated" \\
\hline Truth & Product/Loss & Domain of the "subject of enunciation"
\end{tabular}

Figure 1: Positions/roles of the Lacanian discourse according to active (sending the message) and activated subject (receiving the message $)^{5}$. Source: own elaboration based on Bracher (1993: 54), Žižek (1993: 94), Evans (2006: 45) and Fink (1997: 131)

structures of discourse", according to Bracher (1993: 53), is a means of not only discerning the various complex ways in which discourses psychologically affect large groups of people, but also of bringing about substantial outcomes at the social level, for the Lacanian discourses "produce, respectively, four fundamental social effects: (1) governing/commanding, (2) educating/indoctrinating, (3) desiring/protesting, (4) analyzing/transforming/ revolutionizing". 5

The four discourses, employed by Lacan as "structural positions" to break down the complexity of communication and social relations (Newman 2011: 349), are represented by an algorithm composed of four positions or roles that are taken up by four specific psychological factors: knowledge, ideals, self-division and jouissance ${ }^{6}$ (enjoyment) (Bracher 1993: 53). Both the type of discourse and its concomitant social effect are determined by a particular role, within the algorithm, that each of these aforementioned core elements adopts - that of the agent (see Figure 1). Consequently, at every anticlockwise quarter of a turn, or revolution, referenced from the position of the agent, a discourse and its social effect come into being. Expressed by algebraic symbols, the four fundamental psychological factors, "involved in the production and reception of any text or discourse",

5 While the upper positions are associated with the manifest and evident factors of the discourse's structure (i.e. the enunciated), repressed factors occupy the lower sections (i.e. the enunciation). 6 Even though enjoyment is a somewhat apt translation of jouissance, the term has, according to Lacan, very little to do with the notion of pleasure in itself (nor with 'typical' pleasant situations). Jouissance designates an ambivalent condition, whereby the subject comes to experience both allurement and refusal of "a pleasure that is excessive, leading to a sense of being overwhelmed or disgusted, yet simultaneously providing a source of fascination" (Fink 1997: xii). As such, (the desire for) jouissance is "indifferent - and often inimical - to the well-being both of oneself and of the other person" (Bracher 1993: 20). Jouissance, to put it briefly, is this underlying drive that makes us pursue certain actions and aims, in spite of being aware that doing so might not be best. Gunder (2003a) provides a detailed explanation about the role jouissance may well play in knowledge production to animate other forms of planning theory, practice and, though a bit tangentially, research. are: "master signifiers $\left(\mathrm{S}_{1}\right)$, the network of signifiers or system of knowledge $\left(S_{2}\right)$, the Real ${ }^{7}$ that is simultaneously excluded and produced by the system of knowledge and its master signifiers (a), and the divided subject $(\$)$, split between the identity to which it is interpellated $\left(S_{1}\right)$ and the plus-de-jouir (a), the jouissance that it sacrifices in assuming that identity" (Bracher 1993: 53).

As shown in Figure 1, Lacan named specifically every seat of the algorithmic discursive structure. Along the vertical axis of its quadrantal configuration, the 'active' factors - i.e. those of the subject that utters and sends messages - can be seen on the left-hand side. In the opposite section are the positions of factors prompted by the active factors; that is, those of the subject that receives the message. Along the vertical axis, the upper positions make up the domain of the 'subject of enunciated', where the messages, embedded in any given of the four discourses, are rendered comprehensible enough to reach an interlocutor though without ever, as Lacan (2006 [1966]: 677) states, signifying the subject. Whereas the "top position on each side represents the overt or manifest factor", the lower seats constitute the realm of the "subject of enunciation",

7 The Real is one of Lacan's most enigmatic contrivances. The Real, together with the Imaginary and the Symbolic, are the three registers of subjectivity through which, by means of master signifiers, we are interpellated. Whereas the Symbolic order alludes to the subjective dimension that is equated with language, "the Imaginary and Real refer, respectively, to [...] preverbal and postverbal aspects of the subject. The Imaginary is constituted by schemata of memory and cognition [...] while the Real [...] by those aspects of the subject's being that have been excluded from the categories of language" (Bracher 1993: 22 f.). The Real, thus, "is a lack, or non-place, that language can never fill, but only approach through metaphor and metonym" (Gunder 2003a: 296). Moreover, the Real, as observed by Žižek (1989: 191; italics in the original) is defined by a set of "immediate coincidence of opposite or even contradictory determinations"; the Real, then, can be "the starting point, the basis, the foundation of the process of symbolization [...] which in a sense precedes the symbolic order and is subsequently structured by it when it gets caught in its network" - yet, the Real is "at the same time the product, remainder, scraps of this process of symbolization"; it is, in other words, "the excess which escapes symbolization and is as such produced by the symbolization itself". 
whereby the unconscious arises (even in ways that are contradictory to the uttering "I"), for it "represents the covert, latent, implicit, or repressed factor - the factor that acts or occurs beneath the surface" (Bracher 1993: 54). More specifically, this conscious-unconscious dualism in the production of the Lacanian discourses takes place between the top and bottom left positions: agent and truth, given that the agency is underwritten and given rise by the (hidden) truth, which is simultaneously and helplessly suppressed by it. Finally, the social links (i.e. the vectors connecting the roles) make the four fundamental psychological factors behave as dependent variables whose interrelations imprint, simultaneously, a distinguishing character on each of the four discourses and determine how they relate to one another. ${ }^{8}$

Four roles, four factors, four rotations - four discourses

The discourse of the master: Due to historical reasons, it is the first discourse that is both phylogenetically and ontogenetically "a sort of primary discourse", constituting the outset of the other three discourses $^{9}$, embodying "the alienating functioning of the signifier to which we are all subject" (Fink 1997: 130). It is, moreover, the initial one, since the discourse of the master originates the symbolic order (see footnote 6), "presenting us with a formal expression of [...] the constitution of the subject" (Verhaeghe 2001: 26). In the master's discourse the dominant position is occupied by the master signifier $\left(\mathrm{S}_{1}\right)$ that is "to be seen as intervening $[\ldots]$ in a signifying battery that we have no right, ever, to take as dispersed, as not already forming a network of what is called knowledge" (Lacan 2007 [1991]: 13). In the master's discourse the illusion of equating the subject

8 The social links, oddly enough, are actually somewhat incomplete. Although it could be expected, as the vectors suggest in Figure 1, that there is a feedback or response from the position of 'Product/ Loss' towards that underlying the agency of the message sent (i.e. the position of 'Truth'); "since no receiver is ever completely 'empty', such coincidence is never more than partial: the interpellative force never positions the receiver at the point of demanding from the sender a repetition of precisely the original impetus" (Bracher 1993: 54). Thus, both the top and bottom vector must be, in fact, seen as interrupted. Such a condition is, furthermore, triggered by the disjunctions of impossibility and inability "expressing the disruption of the communicative line" (Verhaeghe 2001: $23 \mathrm{ff}$.).

9 According to Fink (1997: 131) while Hegel had already identified the master's discourse, the other three discourses emerged (much) later. Moreover, only the university's and the analyst's discourse seem to have proceeded from the master's discourse, for it was not until the analyst's discourse had arisen, by the end of the nineteenth century, that the hysteric's discourse came into being. with its own signifying takes place with the express aim of excluding "the unconscious - the knowledge that is not known - as this would jeopardize the ego's sense of certainty and autonomy" (Newman 2011: 349; italics in the original). The matter of concern to the master, in this regard, rather than knowledge, is certainty - as long as everything functions as desired and power is upheld, is not worth bothering with discovering why and/or how things work.

The discourse of the university: ${ }^{10}$ In the university's discourse, the agency is taken up by "knowledge" $\left(\mathrm{S}_{2}\right)$ and, as a result, "systematic knowledge is the ultimate authority, reigning instead of [the master's] blind will, and everything has its reason [...] providing a sort of legitimation or rationalization of the master's will" (Fink 1997: 132). In the discourse of the university it is brought to the fore that any one attempt to produce 'absolutely' neutral knowledge is, after all, a pursuit of domination over the other to whom knowledge is being conveyed (Evans 2006: 46). Thus, the university's discourse stands for the hegemony of knowledge, visible in the modernist predominance of science, for it is "the use of systemic knowledge for rationalization by the agent of the speech act" (Gunder 2004: 307). The success of such rationalisation relies on the way knowledge is "presented as an accumulated, organised and transparent unity, coming straightforwardly to us from the textbooks"; though for it to work a master signifier $\left(\mathrm{S}_{1}\right)$ must come into play (Verhaeghe 2001: 30). All in all, "working in the service of the master signifier, more or less any kind of argument will do, as long as it takes on the guise of reason and rationality" (Fink 1997: 133) - a principle that suggests that (absolute) objectivity is nothing but mere trickery (Gunder 2004: 307; Verhaeghe 2001: 31).

The discourse of the hysteric: the discourse uttered by the hysteric, as opposed to the discourse of the university, "is associated with the practice of protesting, and in this sense it is always pitted against the authority of the Master" (Newman 2011: 349) and any of its (ir) rational articulations embodied by the university's discourse. In the hysteric's discourse, the split subject (\$) becomes the agent and addresses the master signifier $\left(\mathrm{S}_{1}\right)$, demanding the master to "prove his or her mettle by producing something serious by way of knowledge" (Fink 1997: 133). In so doing, the hysterical split subject, in his or her quest for an answer, must turn the other into a master signifier - however, any answer provided "will

10 As clarification, "one should always bear in mind that, for Lacan, university discourse is not directly linked to the university as a social institution" (Žižek 2006c). 
always be beside the point", because the networks of signifiers $\left(\mathrm{S}_{2}\right)$ cannot "produce a particular answer about the particular driving force of the object $a$ at the place of the truth" (Verhaeghe 2001: 29). Thus, the discourse of the hysteric is the complete opposite of the discourse of the university. Whereas the "hysteric gets off on knowledge", knowledge in the university's discourse, instead of an end to be attained, functions as a means whereby the "academic's very existence and activity"11 is justified (Fink 1997: 133). Lacan, ultimately, coupled the discourse of the hysteric with the discourse of science, due to the uniqueness of the relationship the hysteric establishes with knowledge (Fink 1997: 133). Such distinctiveness, furthermore, is characteristic of critical (academic) questioning aimed at producing alternative new knowledge (Gunder 2004: 307).

The discourse of the analyst: Once the final quarter of a turn has taken place, the object petit a (surplus enjoyment), as the cause of desire, is the agent occupying the commanding position triggering the analyst's discourse. In the frame of psychoanalytical treatment, this means that the analyst is, in due course, to become the cause of the analysand's desire. As the analyst's discourse is the actual inverse of the master's discourse, psychoanalysis, in Lacan's view, "is an essentially subversive practice which undermines all attempts at domination and mastery" (Evans 2006: 47). The discourse of the analyst is therefore the sole "effective means for countering the psychological and social tyranny exercised through language" (Bracher 1994: 123), given that it "stands for the emergence of revolutionary-emancipatory subjectivity that resolves the split of university and hysteria" (Žižek 2006c). In order to achieve such a goal, the analyst looks into the precise points in which the conscious and the unconscious split and the analysand "'coughs up' a master signifier that has not yet been brought into relation with any other signifier" (Fink 1997: 135). What the analyst then attempts to do is to relate this 'new' master signifier with other (already existing, or, knowable) signifiers. To that end, "a link must be established between each master signifier and a binary signifier such that subjectification takes place", for the discourse of the analyst occupies itself with unconscious knowledge, "that knowledge that is caught up in the signifying chain and has yet to be

11 In the master's discourse, knowledge, though it remains inaccessible to the master, is cherished to the extent that it produces a surplus suitable for the master's best interest (Fink 1997: 133) which is, in the end, the task of the (manipulated technocratic(ised)) academic. subjectified. Where that knowledge was, the subject must come to be" (Fink 1997: 135). Moreover, Lacan explains that, whereas the analyst deploys the discourse of the analyst, the analysand inevitably resorts to the discourse of the hysteric.

Psychoanalytic theory and, particularly, Lacan's theory of four discourses, all things considered, offer analytical depth without falling into the contradictory trap of becoming a definitive 'master's discourse on truth', because psychoanalysis, "without itself constituting a 'metalanguage'", allows us "to understand the functioning of different discourses in a unique way" (Fink 1997: 198; italics in the original). The theory of four discourses, correspondingly, due to the intrinsic and a priori emptiness of each discourse that shapes the content (i.e. whatever is intended to be analysed) that is deposited into them, can be deployed for almost any given analytical purpose. However, it must be noted that, while the discourses "can contain almost anything", the moment a discourse is reduced to one single interpretation "the whole theory implodes and one returns to the science of the particular" (Verhaegue 2001: 21). I will next discuss how different discourses, mediated by a particular 'subject-planner' (see Table 1), operate within certain - which does not de facto suggest that there cannot be any other - interactions among planning theory, research and practice.

\section{The rise of the 'subject- planner': Lacan's four discourses within the planning theory-research-practice triad}

Lacanian thought has been sharply utilised in the field of planning ${ }^{12}$ to discuss aspects such as the way it may inform planning education (Gunder 2004), planning policy-making (Gunder 2003b, Gunder 2005a), the role of norms and ethics in the exercise of planning (Gunder/ Hillier 2004), the interaction between discourse and practice (Hillier/Gunder 2005) and the interplay among planning, language and ideology (Gunder 2011). ${ }^{13}$ Since

12 According to Hillier and Gunder (2003), while there is a psychogeographic literature, based on Walter Benjamin and Henri Lefebvre, well represented in the works of Pile (1996), Soja (2000) and Thrift (2000), Lacan, in planning circles of theoretical reflection, has in the last couple of decades or so begun to gain relevance as insightful. 13 A wide array of authors like Ernesto Laclau, Chantal Mouffe, Slavoj Žižek, Yannis Stavrakakis, Jodi Dean, Julia Kristeva, among 
the conceptual framework of Lacanian theory, as Gunder (2003a: 311) observes, helps to further and broaden our understanding "of how the world is constituted and how we might do planning differently to accommodate our needs and desires", my intention here is to build up a series of relationships that are established within the planning theory-research-practice triad, when theory, research or practice operates as the agent, and adopts one or various types of the Lacanian discourse. It is important to note that just because one of the discourses is called 'the hysteric's discourse' that hysterics are not inescapably circumscribed within such discourse. Contrariwise, "as an analyst, the hysteric may function within the analyst's discourse; as an academic, the hysteric may function within the discourse of the university" (Fink 1997: 129 f.). Thus, planning theorists, researchers and practitioners, for instance, can move from one discourse to another, without ever altering their physical structure, but varying nonetheless their efficacy, for they "suffer from the obstacles and shortcomings endemic" to whatever discourse they choose to deploy, because irremediably "a particular discourse facilitates certain things and hinders others, allows one to see certain things while blinding one to others" (Fink 1997: 130).

\subsection{The inherent dual condition of the discourse's agency}

Likewise, Lacan's distinction between 'full speech' and 'empty speech' is a determining aspect when analysing the production of linkages among planning theory, research and practice: "as a rule, empty speech is conceived as empty; nonauthentic prattle in which the speaker's subjective position of enunciation is not disclosed, whereas in full speech, the subject is supposed to express his or her authentic existential position of enunciation" (Žižek 1993: 94). Hence, the connection between empty and full speech is to be seen in terms of the dual condition between the "subject of the enunciated" and the "subject of the enunciation". The subject of the enunciated (also known as the subject of the statement or utterance) is "l", the first person - the psychoanalytical ego. In daily discourse, it is the subject to which the agency of speech is attributed, as Van

many others, who have engaged with Lacan's psychoanalytical theory in the light of academic areas such as feminism, cultural studies, political science, ideology, have, likewise, influenced efforts to see planning through a psychoanalytical lens.
Haute (2002: 40) explains: "the subject of the statement [...] refers to the subject as it appears to itself and to the other". Moreover, the subject of the enunciated, according to Lacan (2006 [1966]: 677), despite being a signifier, does not signify the subject, for the "I" gives context to what is being said (i.e. the 'enunciation') and renders it understandable; that is to say, it is by way of the "l" that it is possible to make sense of what has been said. The subject of the enunciation, on the other hand, is the subject of the unconscious. It arises from within speech by means of signifiers that differ from and even contradict the "l" of the enunciated statement. According to Lacan (2008 [2005]: 36), rather than producing discourse the subject of the enunciation is "produced [...], cornered even [...], by discourse" inasmuch as the subject of the enunciation speaks it is spoken. It is through the very act of enunciation that the psychoanalytical unconscious can be accessed, since "the presence of the unconscious, being situated in the locus of the Other, can be found in every discourse, in its enunciation" (Lacan 2006 [1966]: 707). (In Figure 1 it can be seen where, within the discursive algorithmic structure, each subject is operative.)

Full speech, therefore, is not to be understood as simply filling out empty speech, "[q]uite the contrary, [...] it is only empty speech by way of its emptiness (of its distance toward the enunciated content which is posited in it as totally indifferent) which creates the space for 'full speech"' (Žižek 1993: 94). In this regard, if, for instance, "systematic knowledge is the dominant element of a discourse [...], receivers, in order to understand this discourse, must (for a moment, at least) be receptive to a preconstituted knowledge, which means emptying themselves of any knowledge that might interfere with the knowledge in the discourse" (Bracher 1993: 54) and thus be rearticulated by the dominant discourse - such interpellation, it must be remarked, may result in either a product or a loss (see Figure 1). Consequently, it is in full speech that the subject can articulate their position of enunciation - an act that is never even-handed because "publicly reporting on something [...] affects the reported content itself [...] it changes everything" (Žižek 2006a: 18). The rupture between the subject of the enunciated and the subject of the enunciation is well identified in what Lacan calls the "liar-paradox" that is able to utter "an authentic subjective acknowledgement", by, for example, admitting, "I am lying!' I acknowledge the inauthenticity of my being, of my subjective position of enunciation, and in this sense I am telling the truth" (Žižek 1993: 246). This contradictory capacity of the subject renders 
the agency of the Lacanian discourse inconsistent and inauthentic (when the master signifier $\left(\mathrm{S}_{1}\right)$ is exerting the discourse); consistent but inauthentic (in the case of the academic, i.e. knowledge $\left(S_{2}\right)$, occupying the leading seat within the algorithmic structure of the discourse); inconsistent and yet authentic (this dualism is that of the hysterical split subject (\$)); and consistent and authentic (such a triumphant stance being devoted to the analyst (a)) (Žižek 1993: 274).

Lacan's distinction of the subject of the enunciated from the subject of the enunciation affirms the inescapable split, castrated, divided character of the subject, as well as underscoring the fact that the subject is, after all, a speaking being ${ }^{14}$ Put another way, the subject comes into existence through language, because the subject is "that which is represented by a signifier for another signifier, in other words, the subject is an effect of language" (Evans 2006: 198). By the same token, it is the subject, in its inherent dual condition of enunciated-enunciation, that gives way to language (and, by extension, to discourse) in an effort, unavoidably doomed to fail, to clasp an object that supersedes language itself - language and subject are therefore interdependent. ${ }^{15}$

\subsection{From delusional mastery to pragmatic destitution: The subject- planners and their ideological tasks}

Bearing all this in mind, I now turn to explore specific relationships among planning theory, research and practice, according to the element of the triad acting as the agent and the discourse(s) employed. Given the aforementioned dialectical relationship between language and subject, each type of discourse produces a distinct sort of 'subject-planner'; after all, "planners act in and through language" (Gunder 2011: 201). Correspondingly, every subject-planner has a specific ideological role that ultimately sustains the diverse

14 "The result of language acquisition is a loss of a primary condition called 'nature'. From the moment you speak, you become a subject of language (a divided subject for that matter), who tries to grasp an object beyond language, or, more accurately, a condition beyond the separation between subject and object" (Verhaeghe 2001: 25).

15 From an even broader perspective, Gunder (2011: 201), following Lacan (2006 [1966]) and MacCannell (2009: 823), observes that it would not be possible to conceive a society without language inasmuch as a language without society. And, in spite of this vital co-dependency, "language, in itself, cannot fully constitute identity for the subject or comprehensively describe reality" (Gunder 2011: 201). These aspects, furthermore, that escape linguistic articulation, are piled up in the registry of the Real (see footnote 6). ways in which planning theory, research and practice, as depicted in Figure 2, interact and, in turn, renders each of the subject-planners meaningful (see Table 1). ${ }^{16}$ The fact, moreover, that the ideological task shifts, is because ideology "is never just meaning, it always has to also work as an empty container open to all possible meanings" (Žižek 2012). Planning, in a like manner, "is inherently ideological, because ideology constitutes our chosen and dominant belief, or value, systems" (Gunder 2010: 299) which are, consequently, reflected in the discourse deployed to theorise, research or practice planning. ${ }^{17}$

\subsubsection{Universal(ising) planning theory discourse as the voice of planning's veiled big Other, or, the production of solipsistic knowledge}

As shown in Figure 2, the first case is that of universal(ising) planning theory functioning as the master signifier $\left(\mathrm{S}_{1}\right)$; that is to say, occupying the commanding position and making use of the master's discourse. As a result, the 'master' subject-planner emerges and, due to their disregard for the production of knowledge (as long as it serves their purpose), bypasses research to directly encapsulate the exercise of planning in a standardising manner. Think, for example, of the principles emanated from the Congrès International d'Achitecture Moderne (CIAM) putting forward the idea that social problems could be, first, reverted and, in the long run, prevented by impinging a 'perfect' geometrical form upon societies. This straightforward passage from theory to practice clearly states that no substantial epistemological base is, allegedly, needed in order to assert what has to be done and how it has to be done - without, of course, ever having to say why. Discourses of universal(ising) planning theories (e.g., comprehensive and synoptic planning) smack inevitably of contradiction: there is enough evidence to show that socio-spatial reality could never be tamed. Yet they seem honest in their endeavours to propel forward a well-ordered space for people to live pleasantly in, cherish nature (e.g., the Garden City), practice truly participatory democracy, and so on. The catch, though, is that concepts "of complete information,

16 This process, for the first two cases, as it will be shown, is largely imbued by what Gunder (2011: $205 \mathrm{ff}$.) calls "the habitation of 'good' planners".

17 For a more detailed account on ideology in planning theory (and its implications for planning practice), which exceeds the length of this article, see Gunder (2011: $203 \mathrm{ff}$.) and, particularly, Gunder (2010: 300 ff.). 
a harmonious society and of consensus are the Lacanian impossible Real of utopian dreams rather than actual lived reality" (Hillier 2003: 45). Universal(ising) planning theories therefore acquire a tinge of inauthenticity in their tragic fruitless efforts to symbolise and materialise the Real, for all they end up doing is misleading it by producing solipsistic knowledge.

During an interview, Brazilian architect Oscar Niemeyer, who with the urban planner Lúcio Costa conceived Brasilia, Brazil's new capital, avowed that social problems affecting the city, rather than being associated with its layout, resulted directly from the suffusing logic of capitalism and the government's incapacity to cope with social problems that arose therefrom: "[building Brasilia] was a liberating time. It seemed as if a new society was being born, with all the traditional barriers cast aside. It didn't work. Now, Brasilia is too big. The developers, the capitalists are there, dividing society and spoiling the city. Brasilia should stop" (quoted in Glancey 2007). This kind of mastery discourse, while remaining faithful to its original intentions (generating 'a totally free society' - a sort of oxymoronic consistency with his prior inconsistency), fails to realise that those intentions, though authentic, are per se unachievable and that consequences are indeed unimaginable. 'Master' subject-planners, by deploying the discourse of the master to support their actions, are inevitably "caught in a bind between what they want to believe and what they know is true, between espoused theory and actual practice. This often leads to much confusion, most importantly to the idea that planning is purely a technical activity and politics is something that takes place downstream from the technical work and can only mock it up" (Throgmorton 2003: 128). For the purpose of circumventing this complication, universal(ising) planning theory resorts to a hidden structural order that provides the 'master' subjectplanner with enough apparent consistency: the big Other ${ }^{18}$, "this basic element of every ideological edifice [...] the secret order of things; like divine reason, faith or whatever that is controlling our destiny" (Žižek 2012). To put it briefly, the inconsistent universal(ising) theorist

18 "The big Other designates radical alterity, an other-ness which transcends the illusory otherness of the imaginary because it cannot be assimilated through identification. Lacan equates this radical alterity with language and the law, and hence the big Other is inscribed in the order of the symbolic. Indeed, the big Other is the symbolic insofar as it is particularised for each subject. The Other is thus both another subject, in his radical alterity and unassimilable uniqueness, and also the symbolic order which mediates the relationship with that other subject" (Evans 2006: 136). creates an undisclosed structural order that functions as practice's inauthentic underpinning, thereby rendering research useless to practice (this discursive planning logic is easily identifiable in 'contemporary' rhetorical formulations such as the 'smart' or 'creative' city).

\subsubsection{The embodiment of planning's counterfeit Big Other: Planning as value-free and uncritical rationality}

The second case, closely related to the first one, proposes that the agency is performed by a technocratic(ised) planning theory, in the form of knowledge $\left(\mathrm{S}_{2}\right)$ and adopting the discourse of the university. In such an account, the 'expert' subject-planner comes to the fore to control, at their pleasure, research and, in so doing, inculcate any given justification the universal(ising) theorist (i.e. the 'master' subject-planner) might be in need of. Research thus resorts to the discourses of both the master and the university to comply with the technocratic(ised) theory's mandate: to determine practice, which, in turn, is to determine reality. In short, technocratic(ised) theory is to back up power in its quest to define what reality is "rather than discovering what reality 'really' is" (Flyvbjerg 2003: 319). To that end, research may well deploy the discourse of the master and, following the logic of the first case described above, control practice; or, if necessary, research creates the systemic knowledge that justifies the technocratic(ised) theory's will. In the former scenario, power, bestowed, wielded and articulated by 'servant' planning researchers (i.e. 'expert' subjectplanners), "defines, and creates, concrete physical, economic, ecological and social realities" (Flyvbjerg 2003: 320), while in the latter scenario, research helps to turn rationality into rationalisation to then get away with it.

Procedural planning, with its compulsive obsession with the means, rather than the ends, of planning, is an example of how 'technocratic' academics utter a technocratic-master's discourse or a technocraticuniversity's discourse (or even a combination of both) to impose a definitive (mode of) planning praxis. Here the difference between the 'technocratic' and the 'intellectual' planning academic is encountered: whereas the former will insist relentlessly on solving planning's 'wicked problems' by means of a perfectly conceived planning procedure (or method), founded on an "habituated ideology" that helps to fake it till it is possible "to make it as an expert that truly knows" (Gunder 2011: 207/205; italics in the original); the latter, through critical-philosophical 
examination of the wicked problems and "experientially based intuition"' (Gunder 2011: 205), shows that the very way problems are perceived hinders their solutions (or leastways mitigations) (Žižek 2006b: 137). That is why the technocratic(ised) planning academic "rather than getting off on knowledge, would seem to get off on alienation" (Fink 1997: 198). Similarly, Merrifield (2015: 754; italics in the original), drawing on Said's (1993: 8) distinction between amateur and professional intellectuals, their relation to power and authority, and their role in knowledge production, highlights that "one speaks truth to power while the other speaks the truth of power". Not surprisingly, the technocratic planning academic, in order to speak the truth of power, recourses to the discourse of the master, whereas the intellectual planning academic is likely to deploy the discourse of the hysteric to, rebelliously, speak the truth to power.

Planning research, within this interaction, despite being consistent ('planning recipes' are, in themselves, coherent discourses), is helplessly inauthentic for it is at the service of the obfuscating interests of technocratic(ised) planning theory (which, in the end, operates, in this second interaction, as universal(ising) planning theory's shell). As a result, planning is practiced as post hoc fallacy set to, via a 'magical' method, bring disarray into order - however, all the while overlooking the fact that envisioned planning schemes, based upon a symbolic network made of unconscious fantasies and illusions meant to structure social and spatial reality anew (Žižek 1989: 33), have absolutely nothing to do with the actual condition of the existing socio-spatial reality. In order to obviate such divergence, the 'expert' subject-planner must generate a 'feigned' big Other (i.e. a structural order of appearances that makes up practice's inauthentic spearhead) and thus provide the impression that the task of relating processes of decision to the social conditions in which they must operate could be smoothly carried out, rather than be hampered, because rational planning is supposed to stand as universal truth (i.e. to speak the truth of power) and not be subject to alteration through experience (Wildavsky 1973: 152). Such demeanour, more specifically, is nothing but gratuitous: it keeps the 'expert' (as well as the 'master') subject-planner from identifying with their planning "symbolic mask-title", by engendering what Lacan calls "symbolic castration"; that is, "the gap between what I immediately am and the symbolic title that confers on me a certain status and authority" and "in this precise sense, far from being the opposite of power, it is synonymous with power; it is what gives power" (Žižek 2006a: 34). To sum up, the 'expert' subject- planner, embodying and embodied by, the master's and the university's discourse, is able to manipulate research and control practice accordingly, because of their ability not only to not question their symbolic character, but also to cynically speak the truth of power. Yet, this word of "rational scientific management" (Gunder 2010: 301) has an Achilles heel: it can be torn asunder by triggering the universal(ising)/technocratic(ised) theorist's hysteria the questioning of their symbolic label.

\subsubsection{The 'Brownian motion' of critical planning research, or, the hysterical unveiling of universal(ising)/technocratic(ised) planning's big Other}

In the third case displayed in Figure 2, critical research is the hysterical split subject (\$) and hence the agent uttering the discourse of the hysteric that confronts and defies, by frontally speaking truth to power, both universal(ising) and technocratic(ised) theory. As a result, critical-hysterical planning research attempts incessantly - though helplessly flubbing - to reshape practice, by recognising that it is a matter of neither systematisation nor dogmatism, rather of uncertain shambles and unorthodoxy. ${ }^{19}$ There is a large body of planning literature that may well be seen as criticalhysterical research, in which the hysteric's discourse is the "discourse of both the questioning academic and the questioning planning student seeking the production and assurance of new knowledge $\left(\mathrm{S}_{2}\right)$ "' (Gunder 2004: 307). There is, however, a snag: answers, if any are found, never coincide with the ones sought in the first place, because hysterical knowledge, as explained earlier, "is unable to produce a particular answer about the particular driving force of the object $a$ at the place of truth" that is the actual drive of the hysterical agent whose inevitable failure "results in a never-ending battle between the hysterical subject and the master on duty, especially if the latter wants to keep his master-position" (Verhaeghe 2001: 29; italics in the original). ${ }^{20}$

19 Boelens and de Roo (2016) advocate for planning to be reconsidered, for both theoretical and practical (though not, at least advertently, mentioning research) purposes, as "undefined becoming". Similarly, Hillier (2008: 24) proposes, building on Gilles Deleuze's 'planar philosophy', a "multiplanar theory of spatial planning" that stresses the need of embracing, through "a multiple, relational approach of dynamic complexities", the "contingencies of place, time and actant behaviours".

20 Recall here, as an example, Flyvbjerg's (2002: 354) anecdote about the report he prepared, as "a planner-to-be", to summarise arguments to promote either centralisation or decentralisation of 
Thus, the critical-hysterical planning researcher, while being authentic (their demands to the master and the technocractic academic are completely legitimate), is doomed to be inconsistent because of their incapacity to pair questions/problems and answers/solutions together. Nonetheless, there is more than meets the eye in such inability since it is precisely the fundamental conceited desire of both universal(ising) and technocratic(ised) planning theory to find definitive solutions to the problematic situations planners, in practice, have to deal with; the critical-hysterical planning researcher, without being fully aware of it, evades this deception. By way of this elusion, critical-hysterical planning researchers are, paradoxically, short-circuiting the way to a criticalhysterical planning practice - they know something is wrong, denounce it, but fall short of asserting a remedy. This dogged effort, moreover, is what renders them 'idealistic' subject-planners in 'Brownian motion' from theoretical points to practical relays (and vice versa); i.e. with no certainties, with no full knowledge, in constant fluctuation, permanently seeking discovery - and that's how modernist planning's masterly-expert perversion can actually be outdone.

Given that, as explained by Verhaeghe (2001: 29), "structurally, the hysterical discourse results in alienation for the hysterical subject [i.e. 'idealistic' subject-planner] and in [symbolic] castration for the master" subjectplanner, the ideological task of the critical-hysterical planning researcher is the hystericisation - the selfdivision - of the universal(ising)/technocratic(ised) planning theorist. "Hysteria emerges when a subject starts to question or to feel discomfort in his or her symbolic identity" (Žižek 2006a: 35); that is, when the critical-hysterical researcher, speaking truth to power, makes the 'master' and 'expert' subject-planner ask themselves: 'why am I a planner?' Such a question, furthermore, transversally touches a historical and, foremost, an ideological context upon which the symbolic identity is built, because symbolic identities (including, of course, that of planners) are determined by the 'interpellation' that (any given ruling) ideology, through a political and social institutional framework, enforces.

social, educational and health services in Denmark. His proposal, aimed at decentralisation and derived from a British study, to diminish the duration of children's journeys to schools was blatantly disregarded with no significant argument but a handwritten note stating "Cancel, may not apply in Denmark". Evidencing a masterservant relationship (Faludi 1973: 2), Flyvbjerg (2002: 354) came to conclude that centralisation had already been chosen as the way to go and "that the Regional Planning Authority was not to interfere with knowledge that might question the wisdom of the decision".
In sum, "all ideology hails or interpellates concrete individuals as concrete subjects, by the functioning of the category of the subject" (Althusser 2001 [1971]: 117; italics in the original).

The response of the 'master' and 'expert' subjectplanner to their incapacity to provide a true answer as to what it is that makes them planners (and planning ${ }^{21}$ to what they do) - the response that goes well beyond words and is thus the concern of the object petit a - is the production of more signifiers that eventually end up in "the confrontation between the master on the one hand and the fundamental lack in the signifying chain on the other" (Verhaeghe 2001: 29). Such a clash is what eventually opens up the possibility to overcome the universalisation and technocratisation of planning theory, research and practice, for it enables the planner's 'subjective destitution' through which a 'deeper' meaning is neither sought nor imposed.

\subsubsection{The 'master' and 'expert' subject-planner's subjective destitution: De-hystericising the 'universal/technocratic' big Other}

The final interaction is triggered when (micro-)practice ${ }^{22}$ performs as the agency of the discourse of the analyst; i.e. practice as surplus enjoyment (a). Just like the criticalhysterical planning researcher, the analytical planning micro-practitioner calls into question universal(ising) and technocratic(ised) planning theory, but in a much more profound way, for "the analyst's discourse stands for the emergence of revolutionary-emancipatory subjectivity that resolves the split between university and hysteria" whose "goal is to isolate, get rid of, the master signifier that structured the subject's (ideologicopolitical) unconscious" (Žižek 2006c). Analytical planning (micro-)practice, in consequence, not only unveils the manipulated technocratic academic, but also confronts the critical-hysterical researcher, who exerts a reciprocal counteracting influence on the analytical (micro-)practitioner. It is hard to put one's finger on what tells one from the other, given that, at times, they could perfectly be the same; however, not simultaneously.

21 See Alexander (2016) for a compelling and thorough discussion on the seemingly simple question "what is planning?" While reading it, it is worthwhile asking oneself which discourse is being employed and the extent to which more signifiers are being produced (or not). 22 The prefix "micro-" is here employed to underscore opposition to the totalising (i.e. macro) character of universal(ising) and technocracti(sed) planning theory, rather than to denote a spatialgeographical scale. 
Therefore, the relationship between the analytical planning (micro-)practitioner and the critical-hysterical planning researcher resembles, in some way, that between the analyst (analytical (micro-)practice) and the analysand (critical-hysterical research), in which, "while the analyst adopts the analyst discourse, the analysand is inevitably, in the course of analysis, hystericized" (Fink 1997: 136). Intellectual planning academics who, at some point, have taken to the streets and, then, further elaborated their experience - somehow disrespecting the formalities of ethnographic research - in academia are arguably analyst (micro-)practitioners turned into critical-hysterical researchers (and, eventually, back to analyst (micro-)practitioners, and so on and so forth). Moreover, this wavering from analytical (micro-)practice to critical-hysterical research shows that assuming that there is "little to learn from astute practitioners who have no-one to document, illuminate, and appreciate their work" (Forester 2015: 147) cannot be any more bogus. On the contrary, its value relies on how it undermines the dictum of a planning practice suffused with the anxieties of universal(ising)/technocratic(ised) planning theories that disregard any form of subversive counter-practice. ${ }^{23}$

Furthermore, according to Gunder (2004: 308), planning practitioners are not able to appropriately grasp "the underlying ideological distortions and norms comprising the planning field" for they are not fully aware of them. Moreover, continues Gunder, an external and critical point of view is required to reveal the ideological illusions that planning practices engender and that practitioners are embedded in - which is, precisely, the ultimate task of the critical-hysterical planning researcher. Be that as it may, it is also feasible that planning practitioners 'wake up' and confront the internal and dormant contradictions of their profession (as seldom as this might be); that is to say, insightful analysis can also come from within, from 'dissident' planning practitioners willing to alter the 'planning status quo'. Such 'rebellion from within' would, too, entail what Lacan calls "subjective destitution", "the de-hystericization by means of which the subject loses its status as subject" (Žižek 1996: 42) through "stepping out totally of the domain of symbolic identification; cancelling or suspending the entire filth of symbolic authority, the entire filth of the big Other" (Žižek

23 Imagine a 'GIS-ace' land use planner having to come to terms with a land use scheme put together by people from an informal settlement vis-à-vis an official, technical - if not, 'technocraticised' and 'universal(ising)' - one. The ontological and epistemological disparity between one proposal and the other would most likely make it impossible for the technocratic(ised) land use planner to recognise as valid the 'informal one'.
2012). Put another way, the subject-planner (particularly, the 'master' and 'expert') becomes the "'cause of itself' in the sense of no longer looking for a guarantee of his or her existence in another's desire" (Žižek 2012). Together with this comes the realisation that being a planner in its most universal-technocratic sense (as in actually believing oneself to be the only 'holy' one allowed to 'plan') must be replaced by a permanent quest for ways through which, by deploying the discourse of the analyst, to expose "repressed fragments required for displacing dysfunctional societal constructs so that less repressive constructs might then develop, in their place" (Gunder 2003a: 303).

Because of this, planning (micro-)practice is able to rearrange the alleged 'fixity' of the planning theory-research-practice triad - a fixity that, not surprisingly, is safeguarded by either universal(ising) or technocratic(ised) planning theory. Analytical (micro-) practice, as well as critical-hysterical research, in this way, follow a principle of discovery that, instead of seeking to state universal delusional canons, grounds theory in (socio-spatial) reality and recognises the practice of planning as fickle, open to errors, which, in turn, renders the subject-planner as fallible and thus pragmatic i.e. the planner understands that planning in the 'real world' is no picnic and not a simple matter of 'doing everything by the book'. ${ }^{24}$ Overall, the authentic planning micro-practitioner, through the de-hystericisation of the universal(ising) and technocratic(ised) planning theorist, achieves enough realistic consistency to break down the still very much pervasive universalisation and technocratisation of planning theory, research and practice and set, thus, the triad free of ideological interpellations and distorted master signifiers - those "upholstery buttons" that "construct and suture the ego ideal of the fledgling [as well as the 'consolidated'] planner" (Gunder 2003a: 304).

\section{From delusional fantasy to less abstract possibility}

These four reviewed cases show that among planning theory, research and practice, rather than a synergic

24 Gunder's (2003a: 308) argument for "passionate planning for the joy of the Other's desire in our finite world" is, in my view, a good example of the intrinsically imperfect, yet realistic, nature an analytical planning (micro-)practice ought to have and the challenge this encompasses. 


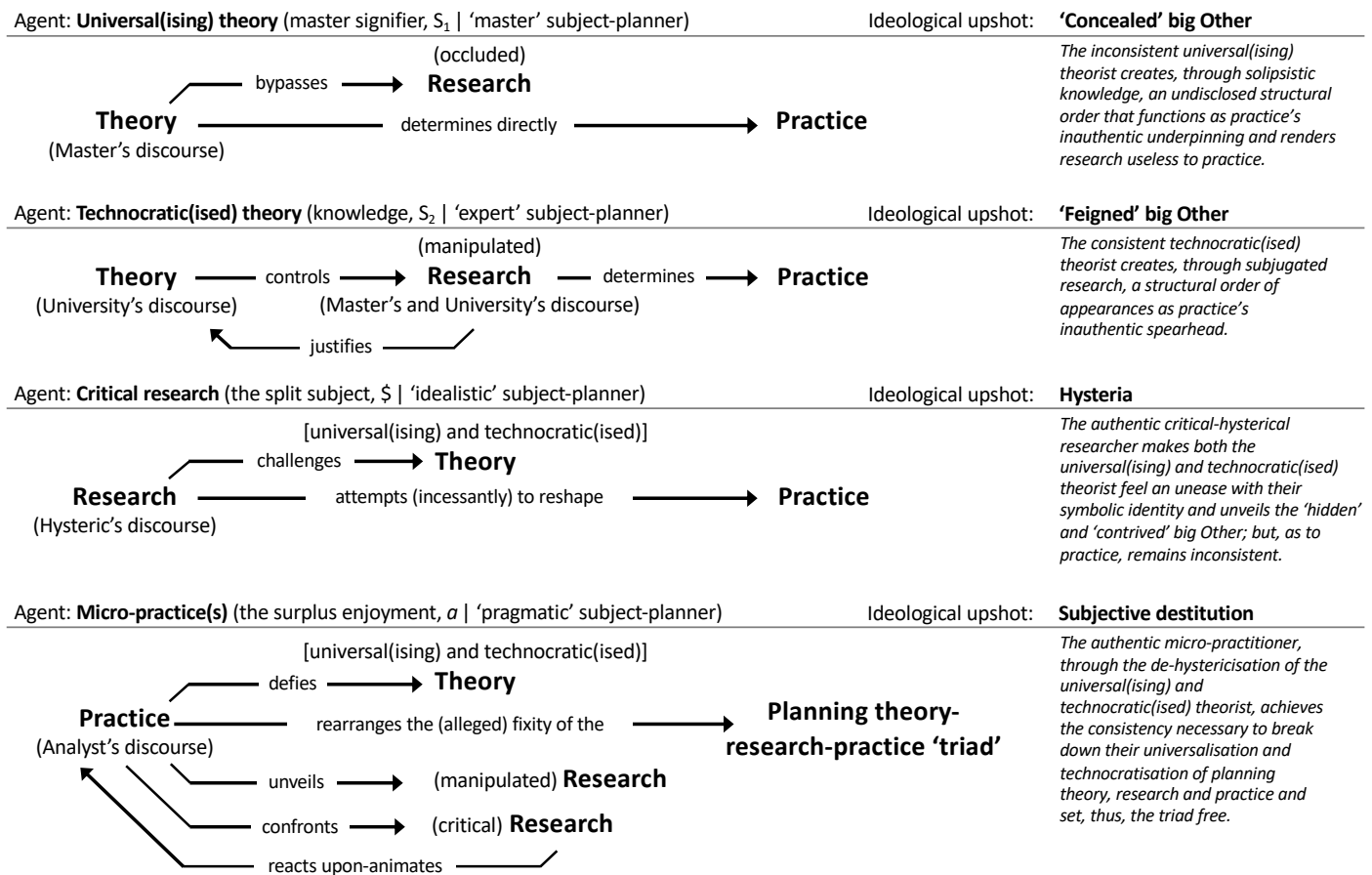

Figure 2: Relationships among elements of the planning theory-research-practice triad according to type of agent and discourse deployed together with their respective ideological upshot

interconnection, linkages - for the most part when universal(ising) and/or technocratic(ised) theory occupies the commanding position of the Lacanian discourse - are generated that attempt to break up, subdue, bypass, or occlude the other two remaining elements of the triad, i.e. research and practice. Knowledge and the way it is created, consequently, evidence a specific "order, stability, authority and regulatory power" (Said 2000: 239). Furthermore, the first two instances - that of universal(ising) and technocractic(ised) planning theory as the agency of, respectively, the master's and the university's discourse - suggest that the 'master' and the 'expert' subject-planner are actually two sides of the same coin, held together by means of an imaginarycomplementary relation that gives rise to a "harmonious totality" in which "each gives the other what the other lacks - each fills out the lack in the other" (Žižek 1989: 193) (for example, when the 'master' subject-planner recourses to technocratic(ised) planning theory to wield research and, accordingly, spell out practice). The 'idealistic' and the 'pragmatic' subject-planner, by the same token, interrelate in a differential-symbolic manner to make up a 'counteractive' coin (i.e. one that rebelliously revolutionises), which defies that of universal(ising)/technocratic(ised) planning theory. To that end, the identity of both the 'idealistic' and the 'pragmatic' subject-planner comprises their difference to one another (that is why the analyst (micro-)practitioner confronts the critical-hysterical researcher; and vice versa) and, far from complementing each other, the 'idealistic' subject-planner takes the place of the lack in the 'pragmatic' subject-planner by embodying what the 'pragmatic' subject-planner is, precisely, in need of (Žižek 1989: 193 f.).

As to knowledge production, this changeover from 'imaginary undisputable totality' to 'symbolic differential pragmatism' implies refraining from (the creation of) universal truths and values (i.e. alienating master signifiers). It, likewise, refers planning theorists, researchers and practitioners, by means of both the hysteric's and the analyst's discourse, to their own desires, "embodied in the fantasies imbricated in its own response" (Bracher 1993: 79), as the foundation for new non-alienating master signifiers to be established (Gunder 2003a: 304). This is what, eventually, makes it possible to not only resist but also fight universalisation and technocratisation, because "when we pass from the perversion to the analytic social link, the agent (analyst) reduces himself to the void, which provokes the subject into confronting the truth of his desire. Knowledge in the position of 'truth' [...] refers to the supposed knowledge 
Table 1: Correlation among discourse's type, social effect, psychological factor, symbolic representation, planning utterer (i.e. 'subjectplanner') and ideological role.

\begin{tabular}{|c|c|c|c|c|c|}
\hline Discourse's type & eSocial effect & Psychological & Algebraic & Planning utterer & Ideological function \\
\hline The Master's & $\begin{array}{l}\text { Govern, } \\
\text { command }\end{array}$ & Knowledge & $\begin{array}{l}\mathbf{S}_{1} \\
\text { (Master } \\
\text { signifier) }\end{array}$ & $\begin{array}{l}\text { Universal(ising) } \\
\text { theorist } \\
\text { (The 'master') }\end{array}$ & $\begin{array}{l}\text { Crafts a 'concealed' planning's big Other } \\
\text { (i.e. a structural hidden order) by way of } \\
\text { producing solipsistic knowledge. }\end{array}$ \\
\hline The University's & $\begin{array}{l}\text { Educate, } \\
\text { indoctrinate }\end{array}$ & Ideals & $\begin{array}{l}\mathbf{S}_{2} \\
\text { (Knowledge) }\end{array}$ & $\begin{array}{l}\text { Technocratic(ised) } \\
\text { theorist } \\
\text { (The 'expert') }\end{array}$ & $\begin{array}{l}\text { Generates a 'feigned' planning's big Other } \\
\text { (i.e. a structural order of appearances to } \\
\text { sublimate the 'master' subject-planner's } \\
\text { will) and preserves the gap (i.e. the } \\
\text { "symbolic castration") that prevents the } \\
\text { 'master'/'expert' subject-planner from } \\
\text { identifying with their planning's symbolic } \\
\text { mask-title. }\end{array}$ \\
\hline The Hysteric's & Desire, protest & Self-division & $\begin{array}{l}\text { \$ } \\
\text { (The split } \\
\text { subject) }\end{array}$ & $\begin{array}{l}\text { Critical researcher } \\
\text { (The 'idealistic') }\end{array}$ & $\begin{array}{l}\text { Makes the 'master'/'expert' subject- } \\
\text { planner feel discomfort with their symbolic } \\
\text { identity (i.e. it triggers hysteria) and } \\
\text { thus exposes planning's 'unseen' and } \\
\text { 'contrived' big Other. }\end{array}$ \\
\hline The Analyst's & $\begin{array}{l}\text { Analyse, } \\
\text { transform, } \\
\text { revolutionise }\end{array}$ & Jouissance & $\begin{array}{l}\text { a } \\
\text { (The surplus } \\
\text { enjoyment) }\end{array}$ & $\begin{array}{l}\text { Micro-practitioner } \\
\text { (The 'pragmatic') }\end{array}$ & $\begin{array}{l}\text { Enables the 'master'/'expert' subject- } \\
\text { planner's "subjective destitution" } \\
\text { whereby the craving for symbolisation } \\
\text { stops internalisation, interpretation and } \\
\text { seeking for "deeper meaning"; in short, } \\
\text { the obliteration of universalisation and } \\
\text { technocratisation. }\end{array}$ \\
\hline
\end{tabular}

Source: Author's elaboration based on Bracher (1993: 53), Žižek (1996: 32), Evans (2006: 45), Žižek (2006a: 34 f.) and Žižek (2012)

of the analyst, and, simultaneously, signals that the knowledge gained here will not be the neutral objective knowledge of scientific adequacy, but the knowledge that concerns the subject (analysand) in the truth of his subjective position" (Žižek 2006c). From such a 'subjective position' the planning theorist, on the one hand, has to forge a shift from "'knowing the better future already" to "what needs to be, but cannot be known"', and the planning practitioner, on the other hand, "from planning content and process to planning conditions, in which the intended developments might or might not occur, or could take a different course" (Boelens/de Roo 2016: 47; italics in the original). And the planning researcher, all the while, is reconciling the two in constant 'Brownian motion'.

Moreover, stripping off the 'appearances' of universal(ising)/technocratic(ised) planning theory's ideological big Other, is, in effect, the conundrum of politics and the idea of utopia, for, as Jameson (2005) sustains, utopia is only a critique of the prevailing ideology. Hence, the planner's "subjective destitution", triggered by critical-hysterical planning research and eventually enabled by analytical planning (micro-) practice, allows us to realise that, though the big Other is what ratifies planners and their actions, as such, there is, as argued by Lacan, no big Other. There is, in other words, no fixed and secured - as universal(ising)/ technocratic(ised) planning theorists so blatantly insist upon - point of reference which guarantees meaning to planning as a whole. Such a recognition, coupled with what Žižek (1991) and Zupančič (2002) refer to as "ethics of the Real", may well lead the way to "planning's redemption from the yoke of modernity" (Gunder 2003a: 307). ${ }^{25}$

25 For a broader reflection on the implications of such a breakthrough see Gunder (2003a: $293 \mathrm{ff}$.). 


\section{Not-a-conclusion: Freely re-dream planning up}

Silent about action, theory can be empty. Ignorant of theory, assessments of practice can be naive (Forester 2015: 145).

Although it is (very) customary for articles to close with a relatively solid and clear statement, it would be nothing but irremediably paradoxical should I do so now, for I am advocating that planning research is to become hysterical; that is, authentic in its inherent inconsistency, open to constant reinterpretation, lacking absolute certainty. It should not be all that startling that such a view be subjected to fierce criticism, after all "people are very narcissistically comforted by a closing statement or any closural gesture, by thinking we have understood, by wrapping things up" (Ronell 2009: 51). The real challenge, therefore, lies somewhere else: in pursuing the exact opposite, in presenting arguments susceptible to other elucidations (i.e. 'to leave them open and radically inappropriable') and in recognising that the dearth of a definitive conclusion turns out to be almost excruciatingly indispensable, because "admitting we haven't really understood, is much less satisfying, more frustrating - and [yet] more necessary" (Ronell 2009: 51). Further, as Forester (2015: 154) claims, the point is not to spark disapprovals, rather to provoke fruitful and enriching debates on improving the analysis of "the complexities - political, normative, institutional, pragmatic and more - of what a diverse range of planners actually do, try to do, and most importantly perhaps of all, might yet do".

There is also an omnipresent risk in assuming that critical-hysterical (as I have put it forward here) reflection can only come from the 'outside', whatever the method; in the sense that it perpetuates the role of the academic researcher trying to decode and deconstruct what the practitioner does (or tries to do). There needs to be more impressions from those 'out there', 'on the job'; but not in the form of mere anecdotic accounts (which, of course, can be deconstructed, ad infinitum, by scholarship), rather as a sort of self-inflicted criticism that can only be triggered by a sense of discomfort with what's being done; by the hysterical question of "why am I a planner?" and "why I am doing this or that?" Then, a far-reaching contribution can be made to the everlasting quest of figuring out how theory and practice may inform and animate each other more substantially and more palpably, for research is no longer the exclusive domain of - in its most 'classical' sense - academic researchers, and it is liberated to those in the field willing to 'subjectively destitute' themselves.

Another important point to clarify is that coupling the notions of "critical-hysterical" and "analytical micro-" with, respectively, planning research and practice, is instrumental and is not therefore an objective in and of itself; the focus relies on their function, and not on their content. They are not mere labels used to 'baptise' new planning paradigms (there are already plenty of them!). Rather, they are intended as means whereby existing and pervading planning paradigms are to be truly challenged and ultimately surpassed; as opposed to simply adding yet another layer to the historical overlapping of 'new' ways of planning that have not significantly improved the way planning is practiced, researched and theorised i.e. they have, at the end of the day, as John Forester puts it in his quote above, remained both theoretically hollow and practically wide-eyed. ${ }^{26}$

The intention, furthermore, has not been to provide an anatomy of the decisive planning theory-researchpractice. The claim is that through the hysteric's and the analyst's discourse, together the 'idealistic' and 'pragmatic' subject-planner (particularly in their 'of enunciation' dimension) could, for instance, articulate Ernst Bloch's (1995 [1959]) 'Not-Yet' (Noch-Nicht) and accordingly connect the present with the future as an open system, as an open possibility. Given the 'Not-Yet' twofold composition - the Not-Yet-Conscious and the Not-Yet-Become - the 'idealistic' and 'expert' subjectplanner would be enabled to defy the perversions of the 'master' and 'expert' subject-planner discourses and to come up with something different, because "the Not-YetConscious is the possibility of the new as developed in the unconscious of the mind" (Torrison 2015: 37). The future that planning is supposed to encourage is not then an "anticipatory consciousness [...] construed around a fantasy, but is developed into a concrete possibility, and

26 A potential explanation for this may arguably be that theorising, researching and, consequently, practicing planning in such a way seems to encompass a bit of what Freud referred to as "transference", provided that, while in a psychoanalytical level we have the tendency to brim ourselves "with the blueprint of our past relationships, practically bursting them on our futures" (Schwartz 2015), planning theory and research that defy the orthodoxies of the past (particularly those derived from modernity) and that actually animate other forms of planning (micro-)practice do have to make their way up, because we keep 'transferring' the blueprints of previous modes of planning theory, research and practice, impeding thus new connections, new schemata, for the very least new hints that may lead to alternative theorising, research and, notably, practice planning. 
it is this possibility that is hinted at in the Not-Yet and which is later evolved" (Torrison 2015: 37).

Similarly, by way of critical-hysterical planning research, it is also possible to untangle transpositional predicaments such as "if planning is everything, maybe it's nothing", put forward by Wildavsky (1973); in the sense that universal(ising)/technocratic(ised) planning theory, through the master's and university's discourse, indeed make planning (specifically research and practice) simultaneously everything and nothing. It is through the contraposition of the statement that planning, too, is nothing (given the vacuousness of inauthentic and inconsistent universal(ising) planning theory) and everything (due to the capacity of this type of theory to either bypass or manipulate, by means of technocratic(ised) university's discourse, planning research and, in so doing, totalise planning practice). That being so, it may well be alleged that critical-hysterical planning research surpasses such a quandary and turns planning neither into nothing nor into everything, but instead into something, something meaningful, something that confronts hysterically, through critical research, universal(ising)/technocratic(ised) planning's ideological big Other - and, through analytical (micro-) practice, outdoes its perversion. In the long run, a truly revolutionary and radical mode of planning theoryresearch-practice can be asserted, because "hysteria is much more subversive than perversion; a pervert has no uncertainties, while [...] the hysterical position is that of doubt, which is an extremely productive position: all new invention comes from hysterical questions" (Žižek 2012, italics added).

Moreover, relating 'hysterical' and 'analytical' planning theory, research and planning to one another so that they do not end up being an unrecognisable totalising unity, requires that the triad be devoid of the action-reaction equalisation; though bearing in mind that this instance might never be fully achieved. In other words, uncertainty, and the anxiety it cannot help but to bring about, has to be fully embraced when theorising, researching and practicing planning. This, too, represents an ethical stance, because "if we're not anxious, if we're ok with things, then we're not trying to explore or figure anything out. Anxiety is the mood par excellence of ethnicity" (Ronell 2009: 49). Though all this reasoning may sound a bit ambiguous, let us not forget that "most ambiguities [...] hold things together in dynamic tension; they don't imply uncertainty but convey honesty; they don't lack clarity but express tension, essential contradictions that form a necessary totality, tensions that must be conveyed and addressed, sometimes sustained. Such provides a richer meaning to words and actions, and to politics" (Merrifield 2015: 760) - so why not then infuse the planning theory-researchpractice triad with 'hysterical ambiguity' and start to freely re-dream planning up?

We acknowledge support by the German Research Foundation and the Open Access Publication Fund of TU Berlin.

\section{References}

Alexander, E.R. (2016): There is no planning - only planning practices: Notes for spatial planning theories. In: Planning Theory 15, 1, 91-103. doi: 10.1177/1473095215594617

Althusser, L. (2001 [1971]): Lenin and Philosophy: And Other Essays. New York.

Bloch, E. (1995 [1959]): The Principle of Hope, Volume 1. Cambridge, MA.

Boelens, L.; de Roo, G. (2016): Planning of undefined becoming: First encounters of planners beyond the plan. In: Planning Theory 15, 1, 42-67. doi: 10.1177/1473095214542631

Bracher, M. (1993): Lacan, Discourse, and Social Change: A Psychoanalytic Cultural Criticism. Ithaca, NY.

Bracher, M. (1994): On the Psychological and Social Functions of Language: Lacan's Theory of Four Discourses. In: Bracher, M.; Alcorn, M.W.; Corthell, R.J.; Massardier-Kenney, F. (eds.): Lacanian Theory of Discourse. New York, 107-137.

Deleuze, G. (1977): Intellectuals and power: A conversation between Michel Foucault and Gilles Deleuze. In: Bouchard, D.F. (ed.): Language, Counter-memory, Practice: Selected Essays and Interviews by Michel Foucault. New York, 205-217.

Evans, D. (2006): An Introductory Dictionary of Lacanian Psychoanalysis. London/New York.

Faludi, A. (1973): What is Planning Theory? In: Faludi, A. (ed.): A Reader in Planning Theory. Oxford, 1-10.

Fink, B. (1997): The Lacanian Subject: Between Language and Jouissance. Princeton, NJ.

Flyvbjerg, B. (2002): Bringing Power to Planning Research: One Researcher's Praxis Story. In: Journal of Planning Education and Research 21, 4, 353-366. doi: 10.1177/0739456X0202100401

Flyvbjerg, B. (2003): Rationality and Power. In: Campbell, S.; Fainstein, S. (eds.): Readings in Planning Theory. Malden, 318-329.

Forester, J. (2015): What kind of research might help us become better planners? In: Planning Theory and Practice 16, 2, 145148. doi: $10.1080 / 14649357.2015 .1028711$

Friedmann, J. (1998): Planning theory revisited. In:EuropeanPlanning Studies 6, 3, 245-253. doi: 10.1080/09654319808720459

Glancey, J. (2007): I pick up my pen. A building appears: An interview with Oscar Niemeyer. In: The Guardian, 01.08.2007.

Gunder, M. (2003a): Passionate planning for the others' desire: An agonistic response to the dark side of planning. In: Progress in Planning 60, 3, 235-319. doi: 10.1016/S0305-9006(02)00115-0 
Gunder, M. (2003b): Planning Policy Formulation from a Lacanian Perspective. In: International Planning Studies 8, 4, 279-294. doi: 10.1080/1356347032000153124

Gunder, M. (2004): Shaping the Planner's Ego-Ideal: A Lacanian Interpretation of Planning Education. In: Journal of Planning Education and Research 23, 3, 299-311. doi: 10.1177/0739456X03261284

Gunder, M. (2005a): Lacan, Planning and Urban Policy Formulation. In: Urban Policy and Research 23, 1, 87-108. doi: 10.1080/0811114042000335287

Gunder, M. (2005b): Obscuring difference through shaping debate: A Lacanian view of planning for diversity. In: International Planning Studies 10, 2, 83-103. doi: 10.1080/13563470500258774

Gunder, M. (2008): Ideologies of Certainty in a Risky Reality: Beyond the Hauntology of Planning. In: Planning Theory 7, 2, 186-206. doi: 10.1177/1473095208090434

Gunder, M. (2010): Planning as the ideology of (neoliberal) space. In: Planning Theory 9, 4, 298-314. doi: 10.1177/1473095210368878

Gunder, M. (2011): Fake it until you make it, and then ... In: Planning Theory 10, 3, 201-212. doi: 10.1177/1473095210387542

Gunder, M.; Hillier, J. (2004): Conforming to the expectations of the profession: A Lacanian perspective on planning practice, norms and values. In: Planning Theory and Practice 5, 2, $217-$ 235. doi: $10.1080 / 14649350410001691763$

Gunder, M.; Hillier, J. (2007): Problematising responsibility in planning theory and practice: On seeing the middle of the string? In: Progress in Planning 68, 2, 57-96. doi: 10.1016/j. progress.2007.07.002

Hillier, J. (2003): 'Agon'izing over consensus: Why Habermasian ideals cannot be 'Real'. In: Planning Theory 2, 1, 37-59. doi: 10.1177/1473095203002001005

Hillier, J. (2008): Plan(e) Speaking: A Multiplanar Theory of Spatial Planning. In: Planning Theory 7, 1, 24-50. doi: 10.1177/1473095207085664

Hillier, J.; Gunder, M. (2003): Planning Fantasies? An Exploration of a Potential Lacanian Framework for Understanding Development Assessment Planning. In: Planning Theory 2, 3 , 225-248. doi: 10.1177/147309520323005

Hillier, J.; Gunder, M. (2005): Not over your dead bodies! A Lacanian interpretation of urban planning discourse and practice. In: Environment and Planning A 37, 7, 1049-1066. doi: 10.1068/ a37152

Jameson, F. (2005): Archaeologies of the Future: The Desire Called Utopia and Other Science Fictions. London.

Lacan, J. (1999 [1975]): The Seminar of Jacques Lacan: On Feminine Sexuality, the Limits of Love and Knowledge (Encore) Book XX. New York.

Lacan, J. (2006 [1966]): Écrits. New York.

Lacan, J. (2007 [1991]): The Seminar of Jacques Lacan: The Other Side of Psychoanalysis Book XVII. New York.

Lacan, J. (2008 [2005]): My Teaching. London.

Liggett, H.; Perry, D.C. (1995): Spatial Practices: An Introduction. In: Liggett, H.; Perry, D.C. (eds.): Spatial Practices. Thousand Oaks, 1-12

MacCannell, J.F. (2009): Eternity or Infinity? Badiou's Point. In: Environment and Planning D 27, 5, 823-839. doi: 10.1068/ d12407

Merrifield, A. (2015): Amateur urbanism. In: City 19, 5, 753-762. doi: 10.1080/13604813.2015.1071119
Newman, S. (2011): Postanarchism and space: Revolutionary fantasies and autonomous zones. In: Planning Theory 10, 4, 344-365. doi: 10.1177/1473095211413753

Pile, S. (1996): The Body and the City: Psychoanalysis, Space and Subjectivity. London.

Ronell, A. (2009): Meaning. In: Taylor, A. (ed.): Examined Life: Excursions with Contemporary Thinkers. New York, 25-60.

Said, E. (1993): Reith Lectures: Representations of an Intellectual. Lecture 4: Professionals and Amateurs (transcript). http:// downloads.bbc.co.uk/rmhttp/radio4/transcripts/1993_reith4. pdf (21.11.2018).

Said, E. (2000): Reflections on Exile and Other Essays. Cambridge, MA.

Schwartz, C. (2015): Tell it about your mother: Can brain-scanning help save Freudian psychoanalysis? In: The New York Times, 24.06.2015. https://www.nytimes.com/2015/06/28/magazine/ tell-it-about-your-mother.html (19.11.2018).

Soja, E. (2000): Postmetropolis: Critical Studies of Cities and Regions. Oxford.

Thrift, N. (2000): Entanglements of Power: Shadows? In: Sharp, J.P.; Routledge, P.; Philo, C.; Padisson, R. (eds.): Entanglements of Power: Geographies of Domination/Resistance. London, 269278.

Throgmorton, J. (2003): Planning as Persuasive Storytelling in a Global-Scale Web of Relationships. In: Planning Theory 2, 2, 125-151. doi: 10.1177/14730952030022003

Torrison, F. (2015): An anatomy of hope. In: plaNext 1, 32-49. doi: 10.17418/planext.2015.2vol.01

Van Haute, P. (2002): Against Adaptation: Lacan's "Subversion" of the Subject. New York.

Verhaeghe, P. (2001): Beyond Gender: From Subject to Drive. New York.

Wildavsky, A. (1973): If planning is everything, maybe it's nothing. In: Policy Sciences 4, 2, 127-153. doi: 10.1007/BF01405729

Žižek, S. (1989): The Sublime Object of Ideology. London.

Žižek, S. (1991): For They Know Not What They Do. London.

Žižek, S. (1993): Tarrying with the Negative: Kant, Hegel, and the Critique of Ideology. Durham, NC.

Žižek, S. (1996): Del deseo al impulso: ¿por qué Lacan no es Lacaniano? In: Atlántica - Internacional Revista de las Artes 14, 31-45.

Žižek, S. (2003): Homo Sacer as the object of the discourse of the University. http://www.lacan.com/hsacer.htm (20.11.2018).

Žižek, S. (2006a): How to Read Lacan. New York.

Žižek, S. (2006b): Philosophy, the "unknown knowns", and the public use of reason. In: Topoi 25, 1-2, 137-142. doi: 10.1007/ s11245-006-0021-2

Žižek, S. (2006c): Jacques Lacan's Four Discourses. http://www. lacan.com/zizfour.htm (21.11.2018)

Žižek, S. (2012): The Pervert's Guide to Ideology. Documentary film directed by Sophie Fiennes. United Kingdom.

Zupančič, A. (2002): Ethics of the Real: Kant, Lacan. London. 